\title{
Eluciadation of the Plant Morphological and Biochemical Characterization of Bhela (Semecarpus Anacardium L.): An Underutilized Plant of Tropics
}

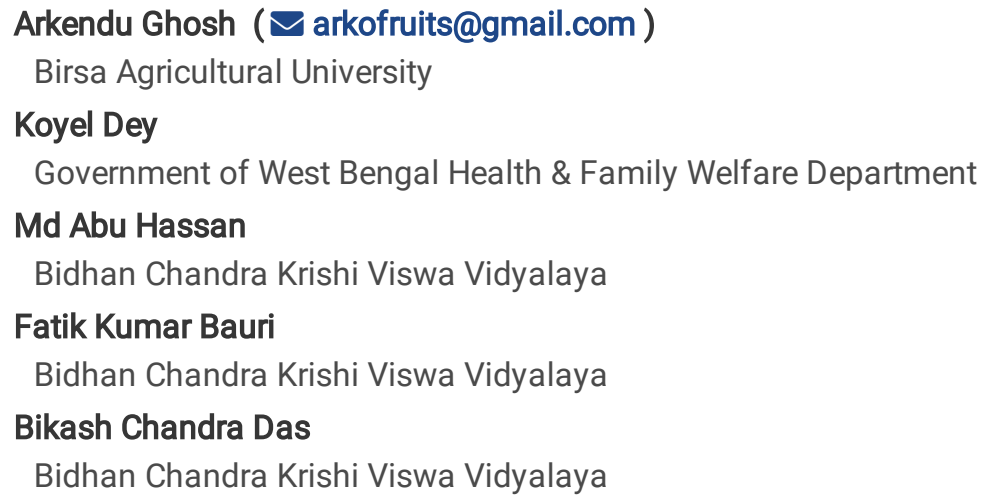

\section{Research Article}

Keywords: Characterization, Growth trend, Reproductive phenology, Semecarpus anacardium, Underutilized fruit

Posted Date: June 17th, 2021

DOI: https://doi.org/10.21203/rs.3.rs-533042/v1

License: (a) (1) This work is licensed under a Creative Commons Attribution 4.0 International License. Read Full License 


\section{Abstract}

Semecarpus anacardium $\mathrm{L}$. is a potential underutilized edible, highly nutritious fruit crop with ample medicinal properties grown in some localized pockets of India. Being a hardy crop, it can be easily used for climate resilient horticulture adaptation. But due to inadequate knowledge it is remains in underused position. Therefore the investigation was carried out to study the morphological and biochemical characteristics of the plant which will help in further improvement of the crop. The plant followed quadratic growth curve in different vegetative characters and leaf chlorophyll in both the years. Positive correlation was observed in different vegetative characters with different weather parameters during first year whereas in second year negatively correlation was recorded with sunshine hours only. The vegetative growth almost ceased during winter season, slow to moderate growth during summer and rapid growth was noticed from rainy to autumn season during experimentation. Leaf chlorophyll content followed an increasing trend during April to November and whereas a decreasing trend from December-March. It bears only terminally in older shoot from May to June with very lower fruit set and retention yield. The ripened fruits of Bhela showed high (23.94 $\left.{ }^{\circ} \mathrm{brix}\right)$ TSS, total sugar, protein $(21.08 \%)$, total carbohydrate, crude fat $(34.91 \%)$ and food energy value $(445.43 \mathrm{kcal} / \mathrm{g})$. The observed performance of the crop with regards to plant morphology, growth rate and fruit quality was indicative for commercial exploitation in future.

\section{Introduction}

Neglected and wild edible fruits were the important sources of food for mankind before dawn of civilization. The tribal groups inhabit in the forests depend on these fruits. They passed on valuable information on utility of fruits from generation to generation. Under estimation of their potential use, non-availability of their complete botanical information, inadequate research on their commercial exploitation, lack of knowledge on their food and nutrition potentiality and fast disappearance of ecosystem and habitat destruction make them remains as an underutilized (Dandin and Krishna, 2016). These crops are locally marketed after harvesting. They are not only medicinally and nutritionally rich but also thrive well under adverse climatic conditions. It can be the considered as a potential source of several desirable traits particularly for resistance to biotic and abiotic stresses. To recover the present crisis of nutritious food supply due to increasing population rate, exploitation of neglected horticultural crops can become a solution for malnutrition and hidden hunger problem (Dandin and Krishna, 2016). Bhela (Semecarpus anacardium L), commonly known as 'Marking nut' or 'Oriental cashew', an important underutilized plant species (family Anacardiaceae) with a boon of medicinal and nutritional properties grown in sub-Himalayan region, tropical and central parts of India and western peninsula of East Archipelago, Northern Australia. Medical industries extensively utilized its medical properties like antiatherogenic, antiinflammatory, antioxidant, antimicrobial, hypoglycemic, anticarcinogenic etc (Semalty et al., 2010). The crop improvement programme mainly depends on the superior mother plants for hybridization and the knowledge of inheritance pattern. Characterization of germplasm is essential to maximize its utility on yield and quality traits, as well as descriptions of available variation and estimates of trait heritability and encourage the development of efficient ex-situ conservation (Rubenstein et al., 2006, Anumalla et al., 2015, Hammer et al., 2003 and De Vicente et al., 2006). Phenotypic characters (Mostly quantitative) are mainly influenced by environments and plant developmental stages and genotypic character is based on the quality of the plant materials which is required for testing the varieties. In this study, an effort has been made to generate and identify Bhela plants with special emphasis on morphological and biochemical traits which is necessary for effective crop improvement programmes. Comprehensive information regarding variability as required by the breeder for evaluation and characterization of various traits, to enhance its productivity and commercial value is lacking. The best efforts were put in describing the underutilized plant taking into consideration all the important morphological and biochemical traits.

\section{Materials And Methods}

\subsection{Experiment I}

\subsubsection{Experimental site}

The investigation was carried out in the Minor Fruit Block under Fruit Research station of Mondouri, Bidhan Chandra Krishi Viswavidyalaya, Nadia, West Bengal, India during November, 2015 to November, 2017.

\subsubsection{Experimental details}

The experiment was done with 4 (four) seasonal treatments viz. - Winter, Summer, Rainy and Autumn and 5 (five) replications in 5 years old plant. 


\subsubsection{Observation recorded}

In the present study a total of 59 morphological (32 qualitative and 27 quantitative) characters, which correspond to the different plant characteristics and plant parts, including leaves, flowers and inflorescences, fruits, nut, and overall architecture have been established. The qualitative characters are follows as- type of planting material, tree habit, tree nature, foliage density, leaf shape, leaf apex shape, leaf base shape, dots on leaf, leaf pubescence, leaf brittleness, young leaf colour, mature leaf colour (above and beneath), young shoot colour, inflorescence position, bearing habit, type of inflorescence, inflorescence shape, petal colour, flower fragrance, pedicel surface, pedicel thickness, pulp texture, pulp taste, mature apple skin colour, apple shape, apple surface, attachment of nut to apple, nut shape, nut base shape, harvesting time, productivity status and biotic stress susceptibility. Quantitative characters which are observed are- tree height, trunk girth, tree spread, canopy volume, leaf length, leaf breadth, leaf petiole length, curvature of the secondary veins to the midrib, internodal length, start of flowering, end of flowering, flowering duration, number of flowers/plant, days taken from flowering to fruit maturity, fruit set, fruit retention, number of fruits harvested per plant, fruit yield, fruit weight, fruit length, fruit breadth, apple weight, apple length, apple breadth, nut weight, nut length and nut breadth. Different characters which were observed were presented pictorially in Fig. 7.

\subsection{Experiment II}

\subsubsection{Experimental site}

The experiment was done in the Quality Control Laboratory, Faculty of Horticulture, Bidhan Chandra Krishi Viswavidyalaya, Nadia, West Bengal, India during November, 2015 to November, 2017.

\subsubsection{Observation recorded}

The biochemical observation was are follows as-

\subsubsection{Total soluble solids (TSS)}

The total soluble solids ( ${ }^{\circ} \mathrm{Brix}$ ) content of fruit was determined with the help of a hand refractometer calibrated at degree Brix ( 0 to $320 B r i x)$ and the values were corrected at $200 \mathrm{C}$ with the help of a temperature correction chart (Mazumdar and Majumder, 2003).

\subsubsection{Titratable acidity}

Five grams of fresh fruit pulp was dissolved in fifty $\mathrm{ml}$ of distilled water by macerating in mortar with pestle. That was then filtered and ten $\mathrm{ml}$ of the filtrate was titrated against $(\mathrm{N} / 10) \mathrm{NaOH}$ solution using $1 \%$ phenolphthalein as an indicator and was expressed in percentage in terms of anhydrous citric acid (Rangana, 1977).

Titratable acidity $=($ Titre value $X$ Normality of alkali X Volume made up X Equivalent weight of citric acid X 100) / Weight of sample X Aliquot X 1000 .

\subsubsection{TSS-Acidity ratio}

TSS-Acidity ratio was calculated by dividing the mean value of TSS by the mean value of titratable acidity.

\subsubsection{Total sugar and reducing sugar}

The total sugar and reducing sugar content were estimated with the help of freshly made mixture containing equal volumes of Fehling's solution A \& B by copper reducing method (A.O.A. C, 1984) using methylene blue as an indicator and was expressed in percentage (Mazumdar and Majumder, 2003).

\subsubsection{Non reducing sugar}

Non-reducing sugar content of fruits were determined by subtracting the value of reducing sugar content from that of the total sugar and multiplying the value with 0.95 and was expressed in percentage (Mazumdar and Majumder, 2003).

Non-reducing sugar $=($ total sugar - reducing sugar $) \times 0.95$

\subsubsection{Sugar-Acidity ratio}


It was calculated by dividing the mean value of total sugar by the mean value of titratable acidity.

\subsubsection{Ascorbic acid}

Ascorbic acid content was estimated by using 2,6-dichlorophenol indophenols dye which was reduced by ascorbic acid to a colourless form (Rangana, 1977). Five grams of fruit pulp was grounded in a mortar with $25 \mathrm{ml}$ of four percent oxalic acid, filter through Whatman no. 1 filter paper and the filtrate was collected in a fifty $\mathrm{ml}$ volumetric flask and the volume was made up to fifty $\mathrm{ml}$ with four percent oxalic acid. Five $\mathrm{ml}$ of the filtrate was taken with $\mathrm{ml}$ of four percent oxalic acid and was titrated against standard 2,6-dichlorophenol indophenols dye to a pink end point. Ascorbic acid was estimated following the method of A.O.A.C. (1984).

Ascorbic acid (mg / 100g pulp) $=($ Titre value X Dye factor X Volume made up / Aliquot of the of the extract Weight or volume of sample) X 100

\subsubsection{Protein}

Protein content of the fruits was estimated based on the principle that the blue colour developed by the reduction of the phosphomolybdic-phosphotunstic components in the Folin-Ciocalteau reagent, purchased from SRL (Mumbai, India), by the amino acids tyrosine and tryptophan present in the protein. The colour developed by the biuret reaction of the protein with the alkaline cupric tartarate were measured colorimetrically at $660 \mathrm{~nm}$ (Lowry, 1951) and expressed in percentage.

\subsubsection{Crude fat}

Crude fat content of fruit was estimated based on the principle that ether is continuously volatilized, condensed and then allowed to pass through the sample to extract ether soluble materials. It was estimated by Soxhlet apparatus (Pelican Socsplus-SCS 04 R) using thimble size $25 \mathrm{~mm}$ X $80 \mathrm{~mm}$. and expressed in percentage (AOAC, 1965).

\subsubsection{Crude fibre}

Crude fibre of fruits was estimated by the principle that a moisture-free and ether extracted sample is digested first with a weak acid solution, then with a weak base solution. The organic residue was collected in a filter crucible. The loss of weight on ignition is crude fibre and expressed in percentage (Sadasivam and Manikam, 1992).

\subsubsection{Total ash content}

Ash content of fruits was estimated by ignite the sample at $600^{\circ} \mathrm{C}$ to burn off all organic material using muffle furnace following the method of AOAC (1965). It was expressed in percentage.

\subsubsection{Total carbohydrate}

Total carbohydrate of fruit was estimated based on the principle that carbohydrate is first hydrolysed into sugars using dilute hydrochloric acid. In hot acidic medium glucose is dehydrated to hydroxymethyl furfural. This compound forms a green coloured product with anthrone, purchased from Merck (Mumbai, India), which was measured colorimetrically at $630 \mathrm{~nm}$ (Sadasivam and Manikam, 1992) using UV/Vis spectrometer and expressed in percentage.

\subsubsection{Total food value}

The total food value was calculated by using the formula (Satpathy et al., 2011$)$ i.e. $\mathrm{kcal} / \mathrm{g}=(3.36 \times \%$ protein fresh weight $)+(3.60 \times \%$ total carbohydrate fresh weight $)+(8.37 \times \%$ fat fresh weight $)$.

\subsubsection{Total phenol}

Total phenolics of fruits was estimated based on the principle that phenols react with an oxidizing agent phosphomolybdate in FolinCiocalteu reagent under alkaline conditions and result is the formation of a blue coloured complex, the molybdenum blue which is measured at $650 \mathrm{~nm}$ colorimetrically by UV/Vis spectrometer (Perkin Elmer, Lambda 25) and expressed as mg per 100g fruit pulp (Thimmaiah, 2004).

\subsection{Statistical analysis}


Analysis of variance (one way classified data) for each parameter was performed using op stat software (online version) and SPSS software. The statistical analysis was done by following completely randomized design (CRD) as per Gomez and Gomez (1984). The significance of different sources of variation was tested by error mean square by Fischer-Snedecor's ' $F$ ' test at probability level of 0.05 percent.

If the treatment regarding a parameter was found significant, Critical Difference (CD) value was calculated to compare the different treatments.

$C D=\sqrt{ }(2 M S E / r) \times$ t0.025; e.d.f.

where,

e.d.f $=$ Error degrees of freedom .

\subsubsection{Trend Analysis}

Trend analysis was done using SPSS software.

\subsubsection{Correlation coefficient $(r)$}

Correlation coefficients for all possible combinations were worked out utilizing the 1 st and 2 nd year data over two years as per AlJibouri et al. (1958).

$\operatorname{Cov}(\mathrm{x} 1, \mathrm{x} 2)$

$r(x 1, x 2)=$

$\sqrt{ } \mathrm{V}(\mathrm{x} 1), \mathrm{V}(\mathrm{x} 2)$

Where, $r(x 1, x 2)=$ correlation between $x 1, x 2$

$V(x 1)=$ variance of $x 1$

$V(x 2)=$ variance of $x 2$

\section{Results And Discussion}

\subsection{Experiment I}

\subsubsection{Qualitative parameters}

\subsubsection{Type of planting material}

Data regarding type of planting material presented in Table 1 revealed that plants seedling origin.

\subsubsection{Tree habit}

Tree habit of the plants were recorded visually (Table 1) showed upright nature. Ghosh et al. (2017) and Motirauji (2012) also reported tree habit of Semecarpus anacardium.

\subsubsection{Tree nature}

Bhela was observed as deciduous nature (Table 1). A similar result was also reported by Ghosh et al. (2017) in Semeacrpus anacardium species.

\subsubsection{Foliage density}

Data pertaining to foliage density of the plants presented in Table 1 was observed as low density. 
Table 1

Type of planting material, tree habit, tree nature and foliage density of bhela

\begin{tabular}{|lllll|}
\hline Crop & $\begin{array}{l}\text { Type of planting } \\
\text { material }\end{array}$ & Tree habit & Tree nature & Foliage density \\
\hline Bhela & Seedling & Upright \& & Deciduous & Low \\
& & open & \\
\hline
\end{tabular}

\subsubsection{Leaf shape}

Data on leaf shape of the plants were recorded visually on mature leaf as obovate to oblong and presented in Table 2. Poornima et al. (2013) also found oblong elliptic leaf shape in Semecarpus species. The report also finds support from Semalty et al. (2010).

\subsubsection{Leaf apex shape}

Leaf apex shape was found as acuminate (Table 2). Poornima et al. (2013) also reported leaf apex shape in S. anacardium.

\subsubsection{Leaf base shape}

The shape of leaf base was noted visually on mature leaf as obtuse (Table 2).

\subsubsection{Dots on leaf}

Data pertaining to the dots on leaf presented in Table 2 showed absence of do on mature leaf (Table 2).

\subsubsection{Leaf pubescence}

Data pertaining to leaf pubescence presented in Table 2 revealed that it was sparsely present on lower part of mature leaf. Ghosh et al. (2017), Poornima et al. (2013) and Semalty et al. (2010) observed similar result (more or less pubescent beneath) in bhela.

Table 2

Leaf shape, leaf apex shape, leaf base shape, dots on leaf and leaf pubescence of bhela

\begin{tabular}{|llllll|}
\hline Crop & Leaf shape & Leaf apex shape & Leaf base shape & Dots on leaf & Leaf pubescence \\
\hline Bhela & Obovate to oblong & Retuse & Obtuse & Absent & Sparse (Lower part \\
& & & & of leaf) \\
\hline
\end{tabular}

3.1.1.10 Leaf brittleness

Brittleness of matured leaf was recorded as brittle and presenting in Table 3.

\subsubsection{Young leaf colour}

In case of young leaf, the leaf colour on both upper and lower surface was observed visually (Table 3) as greenish yellow and pale green respectively. Ghosh et al. (2017) studied young leaf colour in Semecarpus species.

\subsubsection{Mature leaf colour (above and beneath)}

Mature leaf colour was presented in Table 3 and revealed that it was deep green above and pale green beneath on mature leaf (Table

3). Mature leaf colour in bhela is also noticed by Ghosh et al. (2017).

\subsubsection{Young shoot colour}

From the data represented in Table 3 revealed that the colour of young shoot was light green.

\subsubsection{Inflorescence position}

Data on position of inflorescence in the plants showed occurance of inflorescence on older shoot (Table 3).

\subsubsection{Bearing habit}


From the data presented in Table 3 it was found that bearing in bhela was in terminal position of the shoot. Result was in agreement with the observation of Ghosh et al. (2017).

Table 3

Leaf brittleness, young leaf colour, mature leaf colour, young shoot colour, inflorescence position and bearing habit of bhela

\begin{tabular}{|lllllll|}
\hline Crop & $\begin{array}{l}\text { Leaf } \\
\text { brittleness }\end{array}$ & $\begin{array}{l}\text { Young leaf colour (Upper } \\
\text { surface \& Lower } \\
\text { surface) }\end{array}$ & $\begin{array}{l}\text { Mature leaf colour (Upper } \\
\text { surface \& Lower } \\
\text { surface) }\end{array}$ & $\begin{array}{l}\text { Young shoot } \\
\text { colour }\end{array}$ & $\begin{array}{l}\text { Inflorescence } \\
\text { position }\end{array}$ & $\begin{array}{l}\text { Bearing } \\
\text { habit }\end{array}$ \\
\hline Bhela & Brittle & Greenish & Deep & Light green & On old shoot & Terminal \\
& & yellow, Pale green & green, Pale green & & & \\
\hline
\end{tabular}

\subsubsection{Type of inflorescence}

The observation in respect to type of inflorescence (Table 4) showed that it was panicle type.

\subsubsection{Inflorescence shape}

Inflorescence shape was recorded after one month of flowering and recorded as narrowly pyramidal (Table 4).

\subsubsection{Petal colour}

Data pertaining to petal colour of the flowers was recorded as dull greenish yellow with purple inner base and presented in Table 4. Similar result was also noticed by Semalty et al. (2010).

\subsubsection{Flower fragrance}

From the data presenting in Table 4 it was found that flower fragrance is mild in bhela.

\subsubsection{Pedicel surface}

Data on Pedicel surface of mature fruit was observed as moderately rough (Table 4).

Table 4

Type of inflorescence, inflorescence shape, petal colour, flower fragrance and pedicel surface of bhela

\begin{tabular}{|llllll|}
\hline Crop & Type of inflorescence & Inflorescence shape & Petal colour & Flower fragrance & Pedicel surface \\
\hline Bhela & Panicle & Narrowly pyramidal & Dull greenish yellow & Mild & Moderately Rough \\
\hline
\end{tabular}

\subsubsection{Pedicel thickness}

The thickness of pedicel was found to be thick on mature fruit (Table 5).

\subsubsection{Pulp texture}

Data regarding pulp texture was recorded as soft on ripe fruit and presented in Table 5. Premalatha (2000) and Ghosh et al. (2017) also reported similar pulp texture in Semecarpus anacardium.

\subsubsection{Pulp taste}

Data presented in Table 5 in respect to pulp taste was observed as sweet on ripe fruit. Ghosh et al. (2017) noted sweet taste of pulp in Semecarpus species.

\subsubsection{Mature apple skin colour}


Observation on mature apple skin colour was recorded at peak harvesting stage as orange and presented in Table 5. Similar result was also reported by Motirauji (2012) and Ghosh et al. (2017).

\subsubsection{Apple shape}

Data pertaining to apple shape presented in Table 5 recorded as ' $U$ ' shaped at peak harvesting stage. Motirauji (2012) also noticed similar apple shape in Semecarpus anacardium.

Table 5

Pedicel thickness, pulp texture, pulp taste, mature apple skin colour and apple shape of bhela

\begin{tabular}{|llllll|}
\hline \multicolumn{2}{|c|}{ Pedicel thickness } & Pulp texture & Pulp taste & $\begin{array}{l}\text { Mature } \\
\text { apple skin colour }\end{array}$ & Apple shape \\
Crop & & & & \multicolumn{3}{l}{ 'U' shaped } \\
\hline Bhela & Thick & Soft & Sweet & Orange & 'U' \\
\hline
\end{tabular}

\subsubsection{Apple surface}

Observation regarding to apple surface was recorded at peak harvesting stage and presented as rough and dull in Table 6. Ghosh et al. (2017) also recorded apple surface of mature bhela fruit.

\subsubsection{Attachment of nut to apple}

Data on attachment of nut to apple was recorded at peak harvesting stage and revealed that nuts are tightly attached (Table 6) with the apples.

\subsubsection{Nut shape}

Data pertaining to nut shape was recorded as broadly kidney shaped on mature nut (Table 6). Results are in agreements with the finding of Premalatha (2000).

\subsubsection{Nut base shape}

From the Table 6 it was found that shape of nut base was obliquely ovoid on mature nut.

Table 6

Apple surface, attachment of nut to apple, nut shape and nut base shape of bhela

\begin{tabular}{|lllll|}
\hline Crop & Apple surface & $\begin{array}{l}\text { Attachment of nut to } \\
\text { apple }\end{array}$ & Nut shape & $\begin{array}{l}\text { Nut base } \\
\text { shape }\end{array}$ \\
\hline Bhela & Rough \& Dull & Tight & Broad & $\begin{array}{l}\text { Obliquely } \\
\text { ovoid }\end{array}$ \\
& & Kidney & \\
\hline 3.1.1.30 Harvesting time & & \\
\hline
\end{tabular}

Data presented in Table 7 in respect to time of harvesting exhibited peak harvesting was done between 3rd week of November to 1st week of December. This observation regarding time of fruit harvesting was in accordance to Ghosh et al. (2017).

\subsubsection{Productivity status}

Productivity status of the bhela plants was observed as low at the time of harvest (Table 7). It might be due to lower age of the plants which are just start to produce fruits.

\subsubsection{Biotic Stress Susceptibility}

Only few visible sign of leaf disease (burning of leaf tip and edges with mostly upward curling) was recorded in Semecarpus anacardium during the experimental period and grouped as 1 (Table 7 ). 
Table 7

Harvesting time, Productivity status and Biotic-stress susceptibility of bhela

\begin{tabular}{|llll|}
\hline Crop & Harvesting time & Productivity status & Biotic-stress susceptibility \\
\hline Bhela & 3 3rd week of November- 1st week of December & Low & 1 \\
\hline
\end{tabular}

3.1.2 Quantitative parameters

\subsubsection{Plant height}

Data opined to plant height of bhela under different seasons has been presented in Table 8. Results showed that plant height increased in all the seasons and reached peak in autumn after rainy season during two consecutive years and also in pooled data $(3.02,3.14$ and $3.08 \mathrm{~m})$. All the data regarding plant height was statistically non- significant in four seasons in both the year and also in pooled data. In case of monthly variation (Table 9) the data revealed that plant height did not increase from December to February in both the years and pooled data also (2.86, 3.02 and $2.94 \mathrm{~m})$. Thereafter, height increased in a slow manner from March to July in both 1 st year and pooled data (2.87-2.90 $\mathrm{m}$ and 2.95-2.98 m) and March to June in 2nd year (3.03-3.05 m). From August in both 1 st year and pooled data and from July in case of 2 nd year the height was increased in a rapid rate and reached in to a peak in October (3.02 m, $3.14 \mathrm{~m}$ and $3.08 \mathrm{~m})$. After that it was again remain stable in November in both the year.

\subsubsection{Trunk girth}

Data recorded on trunk girth of bhela under different seasons presented in Table 8 revealed a significant variation in case of 2 nd year but in 1st year and pooled data it was remain statistically non-significant. Trunk girth remained consistent both in winter and summer season $(37.00 \mathrm{~cm})$ in $1 \mathrm{st}$ year and then gradually increased. But in case of 2 nd year and pooled data it was increased after winter and reached in to peak in autumn $(37.02,37.04$ and $37.03 \mathrm{~cm})$. Monthly variation (Table 11) in trunk girth remained constant from December to June in 1st and 2nd year and of pooled data (37.00, 37.02 and $37.01 \mathrm{~cm})$. Later, slight increasement was noticed from July to September and then remains consistent up to November (37.02, 37.04 and $37.03 \mathrm{~cm})$ in both the year and of pooled data also. Favourable weather condition might be the cause of slight changes in trunk girth during August to October in both the years which is generally a constant factor throughout the year.

Table 8

Seasonal effect on plant height and trunk girth in bhela

\begin{tabular}{|lllllll|}
\hline & \multicolumn{3}{l}{ Plant Height $(\mathbf{m})$} & \multicolumn{4}{c|}{ Trunk girth (cm) } \\
\cline { 2 - 7 } Season & $\mathbf{2 0 1 6}$ & $\mathbf{2 0 1 7}$ & Pooled & $\mathbf{2 0 1 6}$ & $\mathbf{2 0 1 7}$ & Pooled \\
\hline Winter & 2.86 & 3.02 & 2.94 & 37.00 & 37.02 & 37.01 \\
\hline Summer & 2.88 & 3.04 & 2.96 & 37.00 & 37.03 & 37.08 \\
\hline Rainy & 2.92 & 3.09 & 3.01 & 37.01 & 37.03 & 37.02 \\
\hline Autumn & 3.02 & 3.14 & 3.08 & 37.02 & 37.04 & 37.03 \\
\hline SE $(m)( \pm)$ & 0.077 & 0.067 & 0.070 & 1.456 & 1.479 & 1.467 \\
C.D. $(p \leq 0.05)$ & NS & NS & NS & NS & 4.473 & NS \\
\hline
\end{tabular}


Table 9 Monthly variation in plant height and spread (Both in N-S and E-W) of bhela

\begin{tabular}{|c|c|c|c|c|c|c|c|c|c|}
\hline \multirow[b]{2}{*}{ Months } & \multicolumn{3}{|c|}{ Plant Height (m) } & \multicolumn{3}{|c|}{ Spread (N-S) (m) } & \multicolumn{3}{|c|}{ Spread (E-W) (m) } \\
\hline & 2016 & 2017 & Pooled & 2016 & 2017 & Pooled & 2016 & 2017 & Pooled \\
\hline December & 2.86 & 3.02 & 2.94 & 2.57 & 2.68 & 2.63 & 2.83 & 2.95 & 2.89 \\
\hline January & 2.86 & 3.02 & 2.94 & 2.57 & 2.68 & 2.63 & 2.83 & 2.95 & 2.89 \\
\hline February & 2.86 & 3.02 & 2.94 & 2.57 & 2.68 & 2.63 & 2.83 & 2.95 & 2.89 \\
\hline March & 2.87 & 3.03 & 2.95 & 2.58 & 2.69 & 2.64 & 2.84 & 2.96 & 2.90 \\
\hline April & 2.88 & 3.04 & 2.96 & 2.59 & 2.70 & 2.64 & 2.85 & 2.97 & 2.91 \\
\hline May & 2.89 & 3.04 & 2.96 & 2.59 & 2.71 & 2.65 & 2.86 & 2.98 & 2.92 \\
\hline June & 2.89 & 3.05 & 2.97 & 2.60 & 2.71 & 2.66 & 2.86 & 2.98 & 2.92 \\
\hline July & 2.90 & 3.07 & 2.98 & 2.61 & 2.72 & 2.67 & 2.88 & 3.00 & 2.94 \\
\hline August & 2.92 & 3.09 & 3.01 & 2.63 & 2.74 & 2.69 & 2.90 & 3.02 & 2.96 \\
\hline September & 2.95 & 3.11 & 3.03 & 2.65 & 2.76 & 2.71 & 2.93 & 3.04 & 2.98 \\
\hline October & 3.02 & 3.14 & 3.08 & 2.68 & 2.79 & 2.74 & 2.95 & 3.08 & 3.01 \\
\hline November & 3.02 & 3.14 & 3.08 & 2.68 & 2.79 & 2.74 & 2.95 & 3.08 & 3.01 \\
\hline $\operatorname{SE}(m)( \pm)$ & 0.086 & 0.071 & 0.075 & 0.039 & 0.041 & 0.040 & 0.040 & 0.044 & 0.041 \\
\hline $\begin{array}{l}\text { C.D. } \\
(p \leq 0.05)\end{array}$ & NS & NS & NS & NS & NS & NS & NS & NS & NS \\
\hline
\end{tabular}

3.1.2.3 Plant spread (N-S)

From the data presented in Table 10, it was found that plant spread (N-S) of bhela increased in all the seasons. No significant variation was noticed in plant spread (N-S) within the experimental period. Plant spread reached at peak $(2.68,2.79$ and $2.74 \mathrm{~m})$ in autumn after rainy season in 1 st year, 2 nd year and pooled data. Monthly variation (Table 11) in plant spread (N-S) remained stable from December to February $(2.57,2.68$ and $2.63 \mathrm{~m})$ in 1 st year, 2 nd year and of pooled data. Afterwards plant spread was steadily increased from March to July $(2.58-2.61,2.69-2.72$ and 2.64-2.67 m) and then increasement was accelerated from August to October (2.63-2.68 m, 2.74-2.79 $\mathrm{m}$ and $2.69-2.74 \mathrm{~m}$ ) in 1 st and 2 nd year and pooled data respectively.

Table 10

Seasonal effect on plant spread (N-S and E-W) in bhela

\begin{tabular}{|c|c|c|c|c|c|c|}
\hline \multirow[t]{2}{*}{ Season } & \multicolumn{3}{|c|}{$\begin{array}{l}\text { Plant Spread (N-S) } \\
\text { (m) }\end{array}$} & \multicolumn{3}{|c|}{$\begin{array}{l}\text { Plant Spread (E-W) } \\
\text { (m) }\end{array}$} \\
\hline & 2016 & 2017 & Pooled & 2016 & 2017 & Pooled \\
\hline Winter & 2.57 & 2.68 & 2.63 & 2.83 & 2.95 & 2.89 \\
\hline Summer & 2.59 & 2.70 & 2.65 & 2.85 & 2.97 & 2.91 \\
\hline Rainy & 2.63 & 2.74 & 2.69 & 2.90 & 3.02 & 2.96 \\
\hline Autumn & 2.68 & 2.79 & 2.74 & 2.95 & 3.08 & 3.01 \\
\hline $\operatorname{SE}(m)( \pm)$ & 0.034 & 0.036 & 0.036 & 0.036 & 0.039 & 0.037 \\
\hline $\begin{array}{l}\text { C.D. } \\
(p \leq 0.05)\end{array}$ & NS & NS & NS & NS & NS & NS \\
\hline
\end{tabular}

Page $10 / 25$ 


\subsubsection{Plant spread (E-W)}

From the data presented in Table 10, it was found that plant spread (E-W) of bhela increased in all the seasons. The highest value of $2.95,3.08$ and $3.01 \mathrm{~m}$ was recorded in autumn followed by rainy season in $1 \mathrm{st}$ and 2 nd year and pooled data. Monthly variation (Table 11) in plant spread (E-W) remained stable from December to February $(2.83,2.95$ and $2.89 \mathrm{~m}$ ) in 1st year, 2nd year and pooled data. Plant spread steadily increased later on from March-April but again remained constant in May-June (2.86, 2.98 and $2.92 \mathrm{~m})$ and then increasement was accelerated from June to October (2.88-2.95 m, 3.00-3.08 m and 2.94-3.01 m) in 1st year, 2nd year and of pooled data respectively.

\subsubsection{Canopy volume}

Data on canopy volume of bhela of different seasons was presented in Table 12. Canopy volume was found statistically nonsignificant in 1st year, 2nd year and pooled data. Results showed that canopy volume increased throughout the experimental period and reached at peak after rainy season in autumn $\left(26.65,30.21\right.$ and $\left.28.43 \mathrm{~m}^{3}\right)$. In case of monthly variation (Table 11$)$, it was noticed that canopy volume remained consistent from December to February $\left(23,26.90\right.$ and $\left.24.95 \mathrm{~m}^{3}\right)$ in 1st and 2nd year and of pooled data. Thereafter increased rapidly from March to October (23.26-26.65, 27.17-30.21 and 25.22-28.43 $\left.\mathrm{m}^{3}\right)$ in 1 st year, 2nd year and pooled data respectively. An increase in canopy volume caused simultaneous increase in plant height and plant spread and maximum increase occured between rainy and autumn season which might be due to occurrence of high rainfall as compared to rest of the months. Further the prevailing temperature during rainy/autumn season was more congenial for better vegetative growth of the plant.

\subsubsection{Leaf chlorophyll}

Data on leaf chlorophyll of bhela under different seasons was presented in Table 12. All the data regarding leaf chlorophyll was found statistically significant in 1 st year, 2 nd year and pooled data. Results showed that it was increased throughout the experimental period and reached at peak after rainy season in autumn $(1.49,1.52$ and $1.50 \mathrm{mg} / \mathrm{g})$. In case of monthly variation (Table 11), it was noticed that leaf chlorophyll was decreased from December to March $(1.31-1.29,1.38-1.36,1.35-1.32 \mathrm{mg} / \mathrm{g})$ in $1 \mathrm{st}$ year, 2nd year and of pooled data. After that it was increased from April to November (1.31-1.50, 1.38-1.52 and 1.34-1.51 mg/g) in 1st year, 2nd year and pooled data respectively. 
Table 11

Monthly variation in trunk girth, canopy volume and leaf chlorophyll content of bhela

\begin{tabular}{|llllllllll|}
\hline & \multicolumn{3}{c}{ Trunk girth (cm) } & \multicolumn{5}{c}{ Canopy volume $\left.\mathbf{m}^{3}\right)$} & \multicolumn{3}{c|}{ Leaf chlorophyll (mg/g) } \\
\cline { 2 - 10 } Months & $\mathbf{2 0 1 6}$ & $\mathbf{2 0 1 7}$ & Pooled & $\mathbf{2 0 1 6}$ & $\mathbf{2 0 1 7}$ & Pooled & $\mathbf{2 0 1 6}$ & $\mathbf{2 0 1 7}$ & Pooled \\
\hline December & 37.00 & 37.02 & 1.31 & 1.31 & 1.31 & 24.95 & 1.31 & 1.38 & 1.35 \\
\hline January & 37.00 & 37.02 & 1.30 & 1.30 & 1.30 & 24.95 & 1.30 & 1.36 & 1.33 \\
\hline February & 37.00 & 37.02 & 1.28 & 1.28 & 1.28 & 24.95 & 1.28 & 1.35 & 1.32 \\
\hline March & 37.00 & 37.02 & 1.29 & 1.29 & 1.29 & 25.22 & 1.29 & 1.36 & 1.32 \\
\hline April & 37.00 & 37.02 & 1.31 & 1.31 & 1.31 & 25.40 & 1.31 & 1.38 & 1.34 \\
\hline May & 37.00 & 37.02 & 1.35 & 1.35 & 1.35 & 25.55 & 1.35 & 1.40 & 1.38 \\
\hline June & 37.00 & 37.02 & 1.37 & 1.37 & 1.37 & 25.74 & 1.37 & 1.44 & 1.40 \\
\hline July & 37.01 & 37.03 & 1.39 & 1.39 & 1.39 & 26.07 & 1.39 & 1.46 & 1.42 \\
\hline August & 37.01 & 37.03 & 1.41 & 1.41 & 1.41 & 26.63 & 1.41 & 1.47 & 1.44 \\
\hline September & 37.02 & 37.03 & 1.46 & 1.46 & 1.46 & 27.34 & 1.46 & 1.51 & 1.49 \\
\hline October & 37.02 & 37.04 & 1.48 & 1.48 & 1.48 & 28.43 & 1.48 & 1.52 & 1.50 \\
\hline November & 37.02 & 37.04 & 37.03 & 26.65 & 30.21 & 28.43 & 1.50 & 1.52 & 1.51 \\
\hline SE(m) $( \pm)$ & 1.650 & 1.653 & 1.653 & 1.334 & 0.987 & 1.110 & 0.003 & 0.003 & 0.003 \\
\hline C.D. & NS & NS & NS & NS & NS & NS & 0.009 & 0.007 & 0.007 \\
(p $\leq 0.05)$ & & & & & & & & & \\
\hline
\end{tabular}

Table 12

Seasonal effect on canopy volume and leaf chlorophyll in bhela

\begin{tabular}{|lllllll|}
\hline & \multicolumn{3}{c}{ Canopy volume $\left(\mathrm{m}^{3}\right)$} & \multicolumn{3}{c|}{ Leaf Chlorophyll $(\mathrm{mg} / \mathrm{g})$} \\
\cline { 2 - 7 } Season & $\mathbf{2 0 1 6}$ & $\mathbf{2 0 1 7}$ & Pooled & $\mathbf{2 0 1 6}$ & $\mathbf{2 0 1 7}$ & Pooled \\
\hline Winter & 23.00 & 26.90 & 24.95 & 1.30 & 1.37 & 1.33 \\
\hline Summer & 23.49 & 27.46 & 25.48 & 1.33 & 1.39 & 1.36 \\
\hline Rainy & 24.57 & 28.79 & 26.68 & 1.42 & 1.48 & 1.45 \\
\hline Autumn & 26.65 & 30.21 & 28.43 & 1.49 & 1.52 & 1.50 \\
\hline SE $(m)( \pm)$ & 1.199 & 0.961 & 1.042 & 0.002 & 0.002 & 0.002 \\
\hline C.D. $(p \leq 0.05)$ & NS & NS & NS & 0.005 & 0.006 & 0.005 \\
\hline
\end{tabular}

\subsubsection{Leaf length}

Leaf length recorded on mature leaf has been presented in Table 13. Results clearly showed the maximum leaf length of 34.85 and 34.87 in 1 st year and 2nd year respectively. Similar results in Semecarpus anacardium on leaf length was also reported by Jain and Sharma (2013), Pal (2011) and Ghosh et al. (2017).

\subsubsection{Leaf breadth}

Data pertaining to leaf breadth presented in Table 13 showed the value of $20.13 \mathrm{~cm}$ and $20.15 \mathrm{~cm}$ in 1 st year and 2nd year respectively. Pal (2011), Jain and Sharma (2013) and Ghosh et al. (2017) also recorded similar leaf breadth in Bhela.

\subsubsection{Leaf petiole length}


Data on leaf petiole length presented in Table 13 exhibited 5.87 and $5.85 \mathrm{~cm}$ leaf petiole length in $1 \mathrm{st}$ year and in mean data respectively. Pal (2011) reported $1.2-3.8 \mathrm{~cm}$ petiole length in Semecarpus species.

Table 13

Leaf length, leaf breadth and leaf petiole length of bhela

\begin{tabular}{|llllllllll|}
\hline & \multicolumn{3}{l}{ Leaf length $(\mathrm{cm})$} & \multicolumn{3}{c|}{ Leaf breadth $(\mathrm{cm})$} & \multicolumn{3}{c|}{ Leaf petiole length $(\mathrm{cm})$} \\
\cline { 2 - 11 } Crop & $\mathbf{2 0 1 6}$ & $\mathbf{2 0 1 7}$ & Mean & $\mathbf{2 0 1 6}$ & $\mathbf{2 0 1 7}$ & Mean & $\mathbf{2 0 1 6}$ & $\mathbf{2 0 1 7}$ & Mean \\
\hline Bhela & 34.85 & 34.87 & 34.86 & 20.13 & 20.15 & 20.14 & 5.87 & 5.83 & 5.85 \\
\hline
\end{tabular}

\subsubsection{Curvature of the secondary veins to the midrib}

Curvature of the secondary veins to the midrib was recorded 31,30 and $30.50^{\circ}$ on mature leaf in 1 st and 2nd year and in mean data respectively (Table 14). Pal (2011) also observed 12-25 pairs of main nerves making a wide angle with the coasts in Semecarpus ancardium leaf.

\subsubsection{Internodal length}

Data in respect to internodal length was presented in Table 14. Result showed that it was $3.91 \mathrm{~cm}$ in both the year and mean data also.

Table 14

Curvature of secondary veins to the midrib and internodal length $(\mathrm{cm})$ of bhela

\begin{tabular}{|lllllll|}
\hline & \multicolumn{3}{l}{ Curvature of secondary veins to the midrib } & \multicolumn{3}{c|}{ Internodal length $(\mathrm{cm})$} \\
\cline { 2 - 7 } Crop & $\mathbf{2 0 1 6}$ & $\mathbf{2 0 1 7}$ & Mean & 2016 & 2017 & Mean \\
\hline Bhela & $31^{\circ}$ & $30^{\circ}$ & $30.50^{\circ}$ & 3.91 & 3.91 & 3.91 \\
\hline
\end{tabular}

\subsubsection{Start of flowering}

Observation regarding time of start of flowering has been presented in Table 15. Results showed that flowering started in the 1st week of May in both the year of investigation (03.05.2016 and 01.05.2017). Ghosh et al. (2017) and Motirauji (2012) also recorded flowering initiation time in bhela.

\subsubsection{End of flowering}

The data regarding time of end of flowering was recorded in the 2 nd week of June (Table 15) in both the year of investigation. Motirauji (2012) also observed flowering time in bhela.

\subsubsection{Flowering duration}

The data presented in Table 15 revealed that flowering duration continued for 39 days in both 1 st year and 2 nd year. The present result is in confirmity with the findings of Ghosh et al. (2017) in Semecarpus species.

Table 15

Start of flowering, end of flowering and flowering duration of bhela

\begin{tabular}{|c|c|c|c|c|c|c|c|}
\hline \multirow[t]{2}{*}{ Crop } & \multicolumn{2}{|l|}{ Start of flowering } & \multicolumn{2}{|l|}{ End of flowering } & \multicolumn{3}{|c|}{ Flowering duration (Days) } \\
\hline & 2016 & 2017 & 2016 & 2017 & 2016 & 2017 & Pooled \\
\hline Bhela & $\begin{array}{l}03.05 .2016 \\
\text { (1st week of May) }\end{array}$ & $\begin{array}{l}01.05 .2017 \\
\text { (1st week of May) }\end{array}$ & $\begin{array}{l}\text { 12.06.2016 } \\
\text { (2nd week of June) }\end{array}$ & $\begin{array}{l}\text { 10.06.2017 } \\
\text { (2nd week of June) }\end{array}$ & 39 & 39 & 39.00 \\
\hline
\end{tabular}




\subsubsection{Number of flowers/plant}

The data pertaining to number of flowers per plant is presented in Table 16. The results indicated that the number of flowers per plant was quite higher in 2nd year (13056) as compared to 1st year (8532).

\subsubsection{Days taken from flowering to fruit maturity}

Observation regarding days taken from flowering to fruit maturity was recorded (Table 16) as 194 days in both the year.

Table 16

Number of flower/plant and days taken from flowering to fruit maturity of bhela

\begin{tabular}{|lllllll|}
\hline & \multicolumn{3}{l}{ Number of flower/plant } & \multicolumn{3}{c|}{ Days taken from flowering to fruit maturity } \\
\cline { 2 - 7 } Crop & $\mathbf{2 0 1 6}$ & $\mathbf{2 0 1 7}$ & Mean & $\mathbf{2 0 1 6}$ & $\mathbf{2 0 1 7}$ & Mean \\
\hline Bhela & $\mathbf{8 5 3 2 . 0 0}$ & 13056.00 & 10794.00 & 194 & 194 & 194.00 \\
\hline
\end{tabular}

\subsubsection{Fruit set}

Observation in respect of fruit set (\%) has been presented in Table 17. The percent fruit set was quite low and to the extent of 15.82 and 17.36 in 1st and 2nd year. Lowering in fruit set might be due to prevailing of adverse weather condition (high rainfall and high temperature from May to August in both the year which coincide with flowering time) which ultimately causes drying and shading of maximum quantity of flowers and failed to set fruit finally (Rajan, 2012). Improper pollination due to adverse weather also affects the fruit set in bhela.

\subsubsection{Fruit retention}

Result opined to percentage of fruit retention (Table 17) was revealed that it was $32 \%, 32.42 \%$ and $32.21 \%$ in 1 st year, 2 nd year and mean data respectively. Lower retention in fruit might be due to fact that higher temperature causing altered hormonal status in the fruit which in turns affects the abscission zone (AZ) which ultimately leads shedding of fruit (Roemer et al., 2011).

\subsubsection{Number of fruits harvested per plant}

The data pertaining to number of fruits harvested per plant was presented in Table 17 and it was noted higher in 2nd year (734.80) as compared to 1st year (431.92). Increasement in number of fruit was might be due to increasing age of the plant.

\subsubsection{Fruit yield}

Observation in respect of yield per plant (Table 17) was revealed that yield in Semecarpus anacardium was increased in 2nd year (10 $\mathrm{kg} /$ plant) as compared to $1 \mathrm{st}$ year (5.87 kg/plant). It was might be due to increasing age of the plant which resulted in to harvesting of more number of fruits and yield was gradually increased. Fruit yield in bhela plant was also reported by Motirauji (2012).

Table 17

Fruit set, fruit retention, number of fruits harvested / plant and yield of bhela

\begin{tabular}{|c|c|c|c|c|c|c|c|c|c|c|c|c|}
\hline \multirow[b]{2}{*}{ Crop } & \multicolumn{3}{|c|}{ Fruit set (\%) } & \multicolumn{3}{|c|}{ Fruit retention (\%) } & \multicolumn{3}{|c|}{ Number of fruits harvested /plant } & \multicolumn{3}{|c|}{ Yield (kg/plant) } \\
\hline & 2016 & 2017 & Mean & 2016 & 2017 & Mean & 2016 & 2017 & Mean & 2016 & 2017 & Mean \\
\hline Bhela & 15.82 & 17.36 & 16.59 & 32.00 & 32.42 & 32.21 & 431.92 & 734.80 & 583.36 & 5.87 & 10.00 & 7.94 \\
\hline
\end{tabular}

3.1.2.20 Fruit weight

The data presented in Table 18 clearly revealed that fruit length varied from 12.72 to $12.78 \mathrm{~g}$ during the experimental period. The mean fruit weight was found to be $12.76 \mathrm{~g}$. Results is in conformity with the findings of Deshmukh et al. (2010).

3.1.2.21 Fruit length

Page $14 / 25$ 
Observation in respect of fruit length (Table 18) showed slightly higher value in the 2 nd year $(4.94 \mathrm{~cm})$ as compared to $1 \mathrm{st}$ year (4.88 $\mathrm{cm}$ ). The results are in agreement with the observation of Motirauji (2012).

\subsubsection{Fruit breadth}

Fruit breadth presented in Table 18 revealed slightly higher value in the $2 \mathrm{nd}$ year $(5.10 \mathrm{~cm})$ as compared to $1 \mathrm{st}$ year $(5.06 \mathrm{~cm})$. Similar result was also reported by Motirauji (2012).

Table 18

Fruit weight, fruit length and fruit breadth of bhela

\begin{tabular}{|llllllllll|}
\hline & \multicolumn{3}{l}{ Fruit weight (g) } & \multicolumn{3}{c|}{ Fruit length (cm) } & \multicolumn{3}{c|}{ Fruit breadth (cm) } \\
\cline { 2 - 9 } Crop & $\mathbf{2 0 1 6}$ & $\mathbf{2 0 1 7}$ & Pooled & $\mathbf{2 0 1 6}$ & $\mathbf{2 0 1 7}$ & Pooled & $\mathbf{2 0 1 6}$ & $\mathbf{2 0 1 7}$ & Pooled \\
\hline $\begin{array}{l}\text { Bhela } \\
\text { (Apple + Nut) }\end{array}$ & 12.72 & 12.78 & 12.76 & 4.88 & 4.94 & 4.92 & 5.06 & 5.10 & 5.08 \\
\hline
\end{tabular}

\subsubsection{Apple weight}

Apple weight recorded at peak harvesting stage (Table 19) clearly revealed slight higher value in the 2 nd year ( $8.86 \mathrm{~g}$ ) as compared to 1st year (8.83 g). Deshmukh et al. (2010) also recorded similar findings in different Semecarpus accessions.

\subsubsection{Apple length}

The data presenting in Table 19 clearly opined that apple length varied from 2.69 to $2.72 \mathrm{~cm}$ during the experimental period. The mean fruit length was found to be $2.71 \mathrm{~cm}$.

\subsubsection{Apple breadth}

The data on apple breadth (Table 19) revealed slightly higher value in the 2nd year $(2.78 \mathrm{~cm})$ as compared to mean data $(2.77 \mathrm{~cm})$. The results are in agreement with the findings of Motirauji (2012).

\subsubsection{Nut weight}

Nut weight was recorded (Table 19) slight higher value in the 2nd year (3.92 g) as compared to 1st year (3.89 g). Deshmukh et al. (2010) and Motirauji (2012) also found similar nut weight in Semecarpus anacardium.

\subsubsection{Nut length}

The data presented in Table 19 clearly revealed that nut length varied from 2.19 to $2.22 \mathrm{~cm}$ during the experimental period. The mean nut length was found to be $2.21 \mathrm{~cm}$. Results is in conformity with the findings of Motirauji (2012).

\subsubsection{Nut breadth}

Observation regarding nut breadth was recorded (Table 19) slightly higher value in the 2 nd year $(2.32 \mathrm{~cm})$ as compared to $1 \mathrm{st}$ year $(2.30 \mathrm{~cm})$. Similar observation was also reported by Deshmukh et al. (2010).

Table 19

Weight, length and breadth of apple and nut of bhela

\begin{tabular}{|llllllllll|}
\hline & \multicolumn{3}{l}{ Weight $(\mathbf{g})$} & \multicolumn{3}{c}{ Length (cm) } & \multicolumn{3}{c|}{ Breadth (cm) } \\
\cline { 2 - 10 } Crop & $\mathbf{2 0 1 6}$ & $\mathbf{2 0 1 7}$ & Pooled & $\mathbf{2 0 1 6}$ & $\mathbf{2 0 1 7}$ & Pooled & $\mathbf{2 0 1 6}$ & $\mathbf{2 0 1 7}$ & Pooled \\
\hline Bhela apple & 8.83 & 8.86 & 8.85 & 2.69 & 2.72 & 2.71 & 2.76 & 2.78 & 2.77 \\
\hline Bhela nut & 3.89 & 3.92 & 3.91 & 2.19 & 2.22 & 2.21 & 2.30 & 2.32 & 2.31 \\
\hline
\end{tabular}

\subsubsection{Trends of vegetative growth of bhela}


Vegetative growth pattern of bhela during the years 2015-16 and 2016-17 over different months were recorded to trace the path of change in vegetative growth. Vegetative growth was examined through different linear and non-linear models (curves). Among the curves, linear, logarithmic, inverse, quadratic, cubic, exponential, compound, power, growth and sigmoid were explored and the best model was judged based on maximum $\mathrm{R}^{2}$ and significance of the time coefficients. Ultimately, one best model in each case of each minor fruit crop was retained and explained.

\subsubsection{Plant height}

The trends in plant height of bhela during 2015-16 (Fig. 1a) showed a 2nd degree equation. The quadratic model (curve) fits the best. For 2016-17 (Fig. 1b) the trend also showed a 2nd degree equation where quadratic model (curve) fit the best (Table 20).

\section{Table 20}

Trends in plant height of bhela

\begin{tabular}{|lll|}
\hline Year & Time trend equation & R2 \\
\hline $2015-16$ & $Y t=2.875-0.011 t+0.002 t^{2}(0.014)(0.005)(0.000)$ & $0.977^{\star \star}$ \\
\hline $2016-17$ & $Y t=3.021-0.003 t+0.001 t^{2}(0.007)(0.002)(0.000)$ & $0.982^{\star \star}$ \\
\hline \multicolumn{2}{|l}{ Note: $Y t$ - Height at time $t ; t-$ observation months; ** indicate significance at $1 \%$ level of probability } \\
\hline
\end{tabular}

\subsubsection{Spread (N-S)}

The trends in plant spread (N-S) of bhela during 2015-16 (Fig. 2a) showed a 2nd degree equation. The quadratic model (curve) fits the best. For 2016-17 (Fig. 2b) the trend also showed a 2nd degree equation where quadratic model (curve) fit the best (Table 21).

Table 21

Trends in spread (N-S) of bhela

\begin{tabular}{|lll|}
\hline Year & Time trend equation & R2 \\
\hline $2015-16$ & $Y t=2.572-0.003 t+0.001 t^{2}$ & 0.981 ** \\
& $(0.006)(0.002)(0.000)$ & \\
\hline $2016-17$ & $Y t=2.680-0.002 t+0.001 t^{2}$ & $0.979 * \star$ \\
& $(0.007)(0.002)(0.000)$ & \\
\hline & \\
\end{tabular}

\subsubsection{Spread (E-W)}

The trends in plant spread (E-W) of bhela during 2015-16 (Fig. 3a) showed a 2nd degree equation. The quadratic model (curve) fits the best. For 2016-17 (Fig. 3b) the trend also showed a 2nd degree equation where quadratic model (curve) fit the best (Table 22). 
Trends in spread (E-W) of bhela

\begin{tabular}{|c|c|c|}
\hline Year & Time trend equation & R2 \\
\hline \multirow[t]{2}{*}{$2015-16$} & $Y t=2.828-0.001 t+0.001 t^{2}$ & $0.978 * \star$ \\
\hline & $(0.008)(0.003)(0.000)$ & \\
\hline \multirow[t]{2}{*}{$2016-17$} & $Y t=2.952-0.004 t+0.001 t^{2}$ & $0.981^{\star *}$ \\
\hline & $(0.008)(0.003)(0.000)$ & \\
\hline
\end{tabular}

\subsubsection{Trunk girth}

The trends in trunk girth of bhela during 2015-16 (Fig. 4a) showed a 1st degree equation. The quadratic model (curve) fits the best. The trend also showed a 1st degree equation in 2016-17 where quadratic model (curve) fit the best (Table 23 and Fig. 4b).

Table 23

Trends in trunk girth of bhela

\begin{tabular}{|lll|}
\hline Year & Time trend equation & R2 \\
\hline $2015-16$ & $Y t=37.001-0.002 t(0.003)(0.001)$ & $0.905^{\star \star}$ \\
\hline $2016-17$ & $Y t=37.022-0.002 t(0.003)(0.001)$ & $0.924^{\star \star}$ \\
\hline Note: $Y t-$ Trunk girth at time $t ; t-$ observation months; ${ }^{* \star}$ indicate significance at $1 \%$ level of probability \\
\hline
\end{tabular}

\subsubsection{Canopy volume}

The trends in canopy volume of bhela during 2015-16 (Fig. 5a) showed a 2nd degree equation. The quadratic model (curve) fits the best. The trend also showed a 2nd degree equation where quadratic model (curve) fit the best (Table 24 and Fig. 5b) during the year 2016-17.

Table 24

Trends in canopy volume of bhela

\begin{tabular}{|lll|}
\hline Year & Time trend equation & R2 \\
\hline $2015-16$ & $Y \mathrm{t}=23.325-0.243 \mathrm{t}+0.045 \mathrm{t}^{2}$ & $0.966^{\star *}$ \\
& $(0.279)(0.099)(0.007)$ & \\
\hline $2016-17$ & $Y \mathrm{t}=26.939-0.089 t+0.032 \mathrm{t}^{2}$ & $0.982^{\star *}$ \\
& $(0.191)(0.068)(0.005)$ & \\
\hline Note: Yt- Canopy volume at time $\mathrm{t} ; \mathrm{t}$ - observation months; ** indicate significance at 1\% level of probability
\end{tabular}

\subsubsection{Leaf chlorophyll}

The trends in leaf chlorophyll of bhela during 2015-16 (Fig. 6a) showed a 2nd degree equation. The quadratic model (curve) fits the best. The trend also showed a 2nd degree equation in 2016-17 where quadratic model (curve) fit the best (Table 25 and Fig. 6b). 
Table 25

Trends in leaf chlorophyll of bhela

\begin{tabular}{|lll|}
\hline Year & Time trend equation & R2 \\
\hline $2015-16$ & $Y \mathrm{t}=1.294-0.004 \mathrm{t}+0.002 \mathrm{t}^{2}$ \\
& $(0.016)(0.006)(0.000)$ & $0.968^{\star *}$ \\
\hline $2016-17$ & $\mathrm{Yt}=1.351-0.003 \mathrm{t}+0.001 \mathrm{t}^{2}$ & $0.934^{\star *}$ \\
& $(0.019)(0.007)(0.001)$ & \\
\hline Note: Yt- Leaf chlorophyll at time t; $\mathrm{t}$ - observation months; ** indicate significance at 1\% level of probability \\
\hline
\end{tabular}

The data presented in Table 26 revealed that the plant height was positively and significantly correlated with spread $(\mathrm{N}-\mathrm{S})(\mathrm{r}=0.97)$, spread $(E-W)(r=0.97)$, trunk girth $(r=0.96)$, canopy volume $(r=0.99)$ and leaf chlorophyll $(r=0.93)$ in the 1 st year of investigation (2015-16). Plant height was positively correlated with different weather parameters like average temperature $(r=0.13)$, relative humidity $(r=0.34)$, total rainfall $(r=0.09)$ and sunshine hours $(r=0.21)$. Plant spread $(N-S)$ had high and positive correlation with spread $(E-W)(r=0.99)$, trunk girth $(r=0.95)$, canopy volume $(r=0.98)$ and leaf chlorophyll $(r=0.97)$. Plant spread $(N-S)$ was also positively correlated with different weather parameters like average temperature $(r=0.24)$, relative humidity $(r=0.49)$, total rainfall $(r=$ $0.26)$ and sunshine hours $(r=0.14)$. Plant spread $(E-W)$ had high and positive correlation with trunk girth $(r=0.96)$, canopy volume $(r$ $=0.98)$ and leaf chlorophyll $(r=0.98)$. Plant spread $(E-W)$ was positively correlated with different weather parameters like average temperature $(r=0.23)$, relative humidity $(r=0.49)$, total rainfall $(r=0.26)$ and sunshine hours $(r=0.13)$. Trunk girth was positively and highly correlated with canopy volume $(r=0.96)$ and leaf chlorophyll $(r=0.93)$. Trunk girth was positively correlated with different weather parameters like average temperature $(r=0.02)$, relative humidity $(r=0.34)$, total rainfall $(r=0.08)$ and sunshine hours $(r=$ 0.09). Canopy volume was highly and positively correlated with leaf chlorophyll $(r=0.95)$ and positively correlated with different weather parameters like average temperature $(r=0.15)$, relative humidity $(r=0.38)$, total rainfall $(r=0.13)$ and sunshine hours $(r=$ $0.19)$. Leaf chlorophyll had positive correlation with different weather parameters like average temperature $(r=0.20)$, relative humidity $(r=0.59)$, total rainfall $(r=0.35)$ and sunshine hours $(r=0.02)$.

The plant height was also exhibited positive and highly significant correlation with spread $(N-S)(r=0.99)$, spread $(E-W)(r=0.99)$, trunk girth $(r=0.76)$, canopy volume $(r=0.99)$ and leaf chlorophyll $(r=0.96)$ during the 2 nd year of investigation (Table 27). Plant height was positively correlated with different weather parameters like average temperature $(r=0.31)$, relative humidity $(r=0.61)$, total rainfall $(r=0.42)$ and negatively with sunshine hours $(r=-0.21)$. Plant spread $(N-S)$ had high and positive correlation with spread (E-W) $(r=0.99)$, trunk girth $(r=0.74)$, canopy volume $(r=0.99)$ and leaf chlorophyll $(r=0.95)$. Plant spread $(N-S)$ was positively correlated with different weather parameters like average temperature $(r=0.34)$, relative humidity $(r=0.57)$, total rainfall $(r=0.39)$ and negatively with sunshine hours $(r=-0.14)$. Plant spread $(E-W)$ had high and positive correlation with trunk girth $(r=0.75)$, canopy volume $(r=0.99)$ and leaf chlorophyll $(r=0.96)$. Plant spread $(E-W)$ was positively correlated with different weather parameters like average temperature $(r=0.30)$, relative humidity $(r=0.58)$, total rainfall $(r=0.41)$ and negatively with sunshine hours $(r=-0.18)$. Trunk girth was positively and highly correlated with canopy volume $(r=0.75)$ and leaf chlorophyll $(r=0.77)$. Trunk girth was positively correlated with different weather parameters like average temperature $(r=0.21)$, relative humidity $(r=0.56)$, total rainfall $(r=0.43)$ and negatively with sunshine hours $(r=-0.24)$. Canopy volume was highly and positively correlated with leaf chlorophyll $(r=0.96)$ and positively correlated with different weather parameters like average temperature $(r=0.31)$, relative humidity $(r=0.59)$, total rainfall $(r=0.40)$ and negatively with sunshine hours $(r=-0.19)$. Leaf chlorophyll had positive correlation with different weather parameters like average temperature $(r$ $=0.35)$, relative humidity $(r=0.75)$, total rainfall $(r=0.56)$ and negatively with sunshine hours $(r=-0.37)$. 
Table 26

Correlation coefficient among plant morphological characters, leaf chlorophyll content and weather parameters in bhela during the year 2015-16

\begin{tabular}{|c|c|c|c|c|c|c|c|c|c|c|}
\hline Character & $\begin{array}{l}\text { Plant } \\
\text { height }\end{array}$ & $\begin{array}{l}\text { Spread } \\
\text { (N-S) }\end{array}$ & $\begin{array}{l}\text { Spread } \\
(E-W)\end{array}$ & $\begin{array}{l}\text { Trunk } \\
\text { girth }\end{array}$ & $\begin{array}{l}\text { Canopy } \\
\text { volume }\end{array}$ & $\begin{array}{l}\text { Total Leaf } \\
\text { chlorophyll }\end{array}$ & $\begin{array}{l}\text { Average } \\
\text { Temperature } \\
\left({ }^{\circ} \mathrm{C}\right)\end{array}$ & $\begin{array}{l}\text { Relative } \\
\text { Humidity } \\
(\%)\end{array}$ & $\begin{array}{l}\text { Rainfall } \\
\text { Total } \\
(\mathrm{mm})\end{array}$ & $\begin{array}{l}\text { Sun } \\
\text { Shine } \\
\text { (hours) }\end{array}$ \\
\hline Plant height & 1 & & & & & & & & & \\
\hline Spread (N-S) & 0.978 & 1 & & & & & & & & \\
\hline Spread (E-W) & 0.977 & 0.999 & 1 & & & & & & & \\
\hline Trunk girth & 0.962 & 0.957 & 0.961 & 1 & & & & & & \\
\hline $\begin{array}{l}\text { Canopy } \\
\text { volume }\end{array}$ & 0.999 & 0.987 & 0.987 & 0.966 & 1 & & & & & \\
\hline $\begin{array}{l}\text { Total Leaf } \\
\text { chlorophyll }\end{array}$ & 0.939 & 0.980 & 0.981 & 0.930 & 0.952 & 1 & & & & \\
\hline $\begin{array}{l}\text { Average } \\
\text { Temperature } \\
\left({ }^{\circ} \mathrm{C}\right)\end{array}$ & 0.134 & 0.245 & 0.236 & 0.024 & 0.157 & 0.203 & 1 & & & \\
\hline $\begin{array}{l}\text { Relative } \\
\text { Humidity (\%) }\end{array}$ & 0.347 & 0.498 & 0.496 & 0.347 & 0.383 & 0.596 & 0.275 & 1 & & \\
\hline $\begin{array}{l}\text { Rainfall Total } \\
(\mathrm{mm})\end{array}$ & 0.099 & 0.267 & 0.267 & 0.089 & 0.137 & 0.352 & 0.458 & 0.853 & 1 & \\
\hline $\begin{array}{l}\text { Sun Shine } \\
\text { (hours) }\end{array}$ & 0.213 & 0.147 & 0.139 & 0.099 & 0.197 & 0.024 & 0.490 & -0.511 & -0.374 & 1 \\
\hline
\end{tabular}


Table 27

Correlation coefficient among plant morphological characters, leaf chlorophyll content and weather parameters in bhela during the year 2016-17

\begin{tabular}{|c|c|c|c|c|c|c|c|c|c|c|}
\hline Character & $\begin{array}{l}\text { Plant } \\
\text { height }\end{array}$ & $\begin{array}{l}\text { Spread } \\
(\mathrm{N}-\mathrm{S})\end{array}$ & $\begin{array}{l}\text { Spread } \\
\text { (E-W) }\end{array}$ & $\begin{array}{l}\text { Trunk } \\
\text { girth }\end{array}$ & $\begin{array}{l}\text { Canopy } \\
\text { volume }\end{array}$ & $\begin{array}{l}\text { Total Leaf } \\
\text { chlorophyll }\end{array}$ & $\begin{array}{l}\text { Average } \\
\text { Temperature } \\
\left({ }^{\circ} \mathrm{C}\right)\end{array}$ & $\begin{array}{l}\text { Relative } \\
\text { Humidity } \\
(\%)\end{array}$ & $\begin{array}{l}\text { Rainfall } \\
\text { Total } \\
(\mathrm{mm})\end{array}$ & $\begin{array}{l}\text { Sun } \\
\text { Shine } \\
\text { (hours) }\end{array}$ \\
\hline Plant height & 1 & & & & & & & & & \\
\hline $\begin{array}{l}\text { Spread (N- } \\
\text { S) }\end{array}$ & 0.995 & 1 & & & & & & & & \\
\hline $\begin{array}{l}\text { Spread (E- } \\
\text { W) }\end{array}$ & 0.998 & 0.997 & 1 & & & & & & & \\
\hline Trunk girth & 0.760 & 0.746 & 0.755 & 1 & & & & & & \\
\hline $\begin{array}{l}\text { Canopy } \\
\text { volume }\end{array}$ & 0.999 & 0.997 & 0.999 & 0.758 & 1 & & & & & \\
\hline $\begin{array}{l}\text { Total Leaf } \\
\text { chlorophyll }\end{array}$ & 0.968 & 0.958 & 0.961 & 0.776 & 0.964 & 1 & & & & \\
\hline $\begin{array}{l}\text { Average } \\
\text { Temperature } \\
\left({ }^{\circ} \mathrm{C}\right)\end{array}$ & 0.3178 & 0.341 & 0.302 & 0.216 & 0.311 & 0.355 & 1 & & & \\
\hline $\begin{array}{l}\text { Relative } \\
\text { Humidity } \\
\text { (\%) }\end{array}$ & 0.610 & 0.574 & 0.590 & 0.567 & 0.595 & 0.751 & 0.452 & 1 & & \\
\hline $\begin{array}{l}\text { Rainfall } \\
\text { Total (mm) }\end{array}$ & 0.423 & 0.398 & 0.412 & 0.434 & 0.410 & 0.565 & 0.535 & 0.903 & 1 & \\
\hline $\begin{array}{l}\text { Sun Shine } \\
\text { (hours) }\end{array}$ & -0.212 & -0.148 & -0.185 & -0.246 & -0.191 & -0.374 & -0.178 & -0.827 & -0.772 & 1 \\
\hline
\end{tabular}

\section{Conclusions}

From the results it is concluded that weather parameters influenced heavily on both vegetative and reproductive characters of the underutilized fruit crop (bhela). It provides fundamental basis for the classification based on vegetative, inflorescence and fruit physico-chemical characteristics. The performance of crop with regards to productivity and fruit quality was quite satisfactory and indicative for commercial exploitation in future. This information can be applied in crop improvement, proper conservation and better use of this underutilized plant species. It is an essential work before carrying out comprehensive molecular studies. Accordingly, the results also provide baseline information on $S$. anacardium which will help to select superior germplasms of the crop.

\section{Declarations}

Fund The authors did not receive support from any organization for the submitted work.

Conflicts of interest The authors declare that they have no conflict of interest.

Availability of data and material All the data analyzed during the study are available from the corresponding author on reasonable basis.

Authors' contributions Conceptualization: Arkendu Ghosh, Koyel Dey; Formal analysis and investigation: Koyel Dey, Fatik Kumar Bauri, Bikash Chandra Das, Arkendu Ghosh; Writing original draft preparation: Arkendu Ghosh, Md. Abu Hassan, Koyel Dey; Writingreview and editing: Fatik Kumar Bauri, Koyel Dey, Md. Abu Hassan; Supervision: Bikash Chandra Das.

Ethics approval 'Not applicable' for that section. 
Acknoledgements We wish to thank Department Fruit Science, B.C.K.V., Mohanpur, Nadia, West Bengal, India for all the laboratory analysis facility. Special thanks to Prof. F. K. Bauri for supporting the overall field investigation and to Prof. P. K. Sahu for helping in Statistical analysis. We also thanks to Dr. Amarenda Nath Dey, Department of Forestry and Dr. Nilesh Bhowmick, Head, Department of Pomology and Post Harvest Technology, U.B.K.V., Pundibari, Cooch Behar, West Bengal, India for their inspiration, encouragement and support in selecting the underutilize crop species.

\section{References}

Al Jibouri HA, Miller PA, Robinson HF (1958) Genotypic and environmental variances and covariances in an upland cotton cross of interspecific origin. Agron J 50:633-636.

Anumalla M, Roychowdhury R, Geda CK, Mazid M, Rathoure AK (2015) Utilization of plant genetic resources and diversity analysis tools for sustainable crop improvement with special emphasis on Rice. Int J Adv Res 3(3):1155-1175.

AOAC (1965) Official Methods of Analysis of Association of Official Agricultural Chemists, 10th edn., Washington, D.C.

AOAC (1984) Official Methods of Analysis of Association of Official Agricultural Chemists, Washington, D.C., PP. 16.

Dandin SB, Krishna NK (2016) Neglected and underutilized fruit species - an insurance against global mal and under nutrition.

Regional Expert Consultation of NUS, FAO Regional Office, Bangkok; www.bioversityinternational.org. pp. 1-40.

De Vicente MC, Guzma'n FA, Engels J, Rao VR (2006) Genetic characterization and its use in decision making for the conservation of crop germplasm. In: Ruane J, Sonnino A(eds) The role of biotechnology in exploring and protecting agricultural genetic resources. Food and Agriculture Organization, Rome, pp. 121-128.

Ghosh A, Dey K, Das BC, Bauri FK, Ghosh SK (2017) A review on potential underutilized medicinal fruit plant Bhela (Semecarpus anacardium L.). J Crop Weed 13(3):209-211.

Gomez KA, Gomez AA (1984) Statistical procedures for agricultural research (2 ed.). John wiley and sons, NewYork, 680p.

Hammer K, Arrowsmith N, Gladis T (2003) Agrobiodiversity with emphasis on plant genetic resources. Naturwissenschaften 90:241250.

Deshmukh NA, Waskar DP, Sable PB (2010) Variability in marking nut (Semecarpus anacardium L.) accessions from Marathwada region of Maharashtra state. J Horti Sci 5(1):71-74.

Jain P, Sharma HP (2013) A potential ethno-medicinal plant: Semecarpus anacardium Linn. - a review. Int J Res Pharm Chem 3(3):564-572.

Lowry OH, Rosebrough NJ, Farr AL, Randall RJ (1951) Protein measurement with the Folin phenol reagent. J Biol Chem 193:265.

Mazumdar BC, Majumder K (2003) Determination of Chemical Constituents. In: Methods on Physico-chemical Analysis of Fruits. Daya Publishing House, Delhi, pp. 93-139.

Motirauji GP (2012) Survey for selection of superior types of marking nut (Semecarpus anacardium L.) in Marathwada region. M.Sc. Thesis submitted to the Department of Horticulture College of Agriculture, Parbhani Marathwada Krishi Vidyapeeth,Parbhani 431402 (M.H.), India.

Pal D (2011) Antioxidant potentials and pharmacological activities of Marking Nut (Semecarpus anacardium L.). In: Nuts and seeds in health and disease prevention. Anacardium - an overview. Science Direct. pp. 2-3.

Poornima M, Anita S, Kumar GV (2013) Semecarpus anacardium: A review Int J Ayurvedic Medical J 1(6):69-76.

Premalatha B (2000) Semecarpus anacardium Linn. Nuts- A boon in alternative medicine. Indian J Exp Biol 38:1177-1182.

Rajan S (2012) Phenological Responses to Temperature and Rainfall: A case Study of Mango. In: Tropical fruit tree species and climate change. Editors: B Sthapit, V R Rao, S Sthapit. Biodiversity and International Publisher, New Delhi, India, pp. 71-96.

Page $21 / 25$ 
Rangana S (1977) Manual of Analysis of Fruits and Vegetable Products. Tata and Mc. Graw Hill Publishing Company Limited, New Delhi, India.

Roemer MG, Hegele M, Wunsche JN, Huomg PT (2011) Possible physiological mechanisms of premature fruit drop in mango (Mangifera indica L.) Northern Vietnam. Acta Hort 903:140.

Rubenstein DK, Smale M, Widrlechner MP (2006) Demand for genetic resources and the U.S. National Plant Germplasm System. Crop Sci 46:1021-1031.

Sadasivam S, Manikam A (1992) In: Biochemical Methods for Agricultural Sciences, Wiley Eastern Ltd., New Delhi. pp. 11-21.

Satpathy G, Tyagi YK, Gupta RK (2011) Preliminary evaluation of nutraceutical and therapeutic potential of raw Spondias pinnata K., an exotic fruit of India. Food Res Int 44:2076-2087.

Semalty M, Semalty A, Badola A, Joshi GP, Rawat MSM (2010) Semecarpus anacardium Linn.: A review. Pharmacog Rev 4(7):88-94.

Thimmaiah SR (2004) Standard Methods of Biochemical Analysis. Kalyani Publishers, Noida, U.P., pp. 287-288.

\section{Figures}
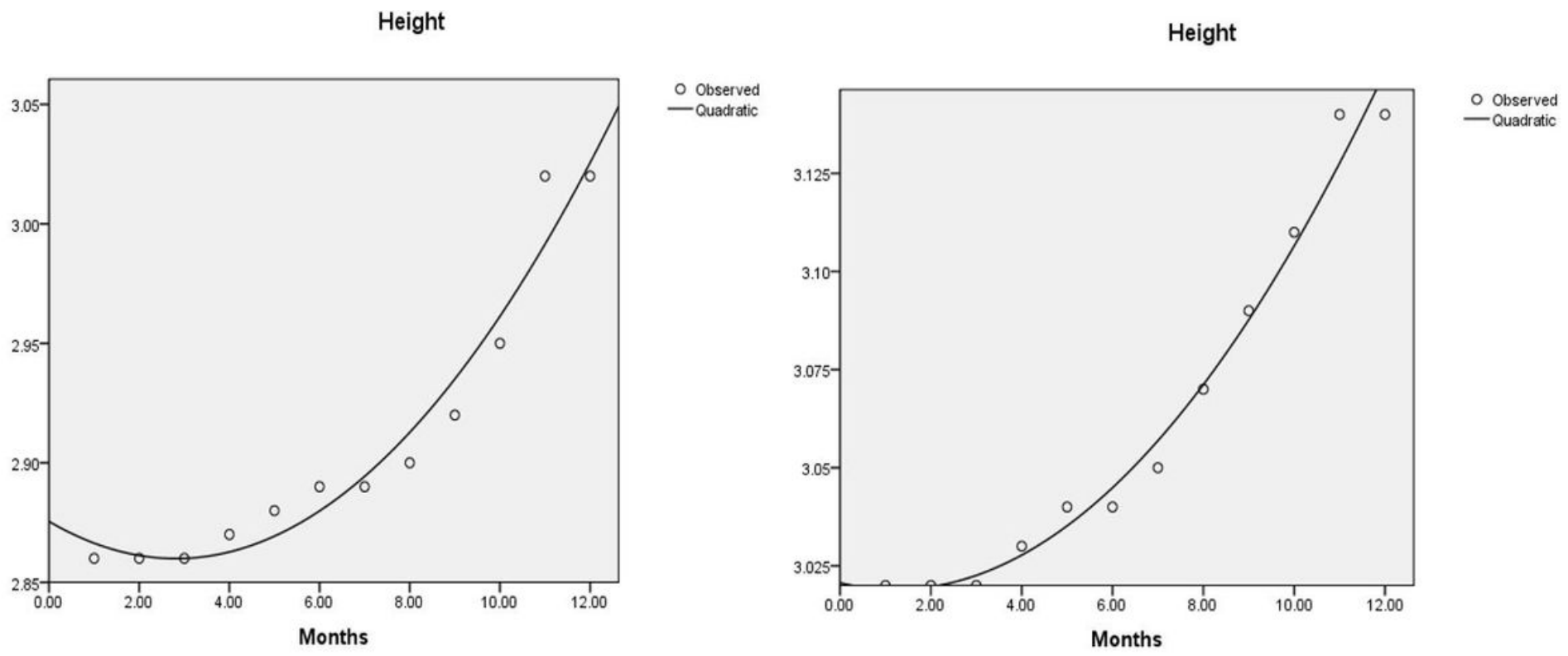

Figure 1

a Quadratic model for height during 2016-17. b Quadratic model for height during 2015-16. 
Spread

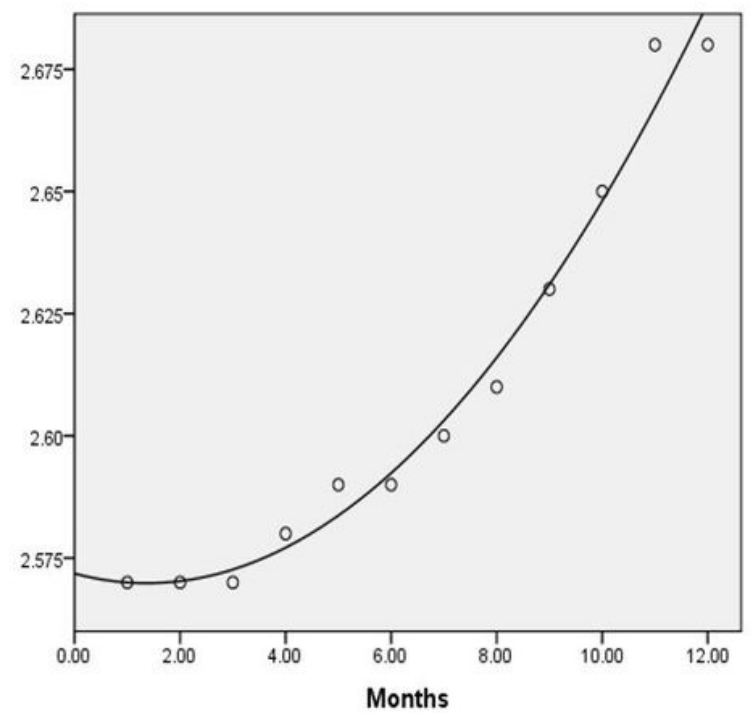

Spread
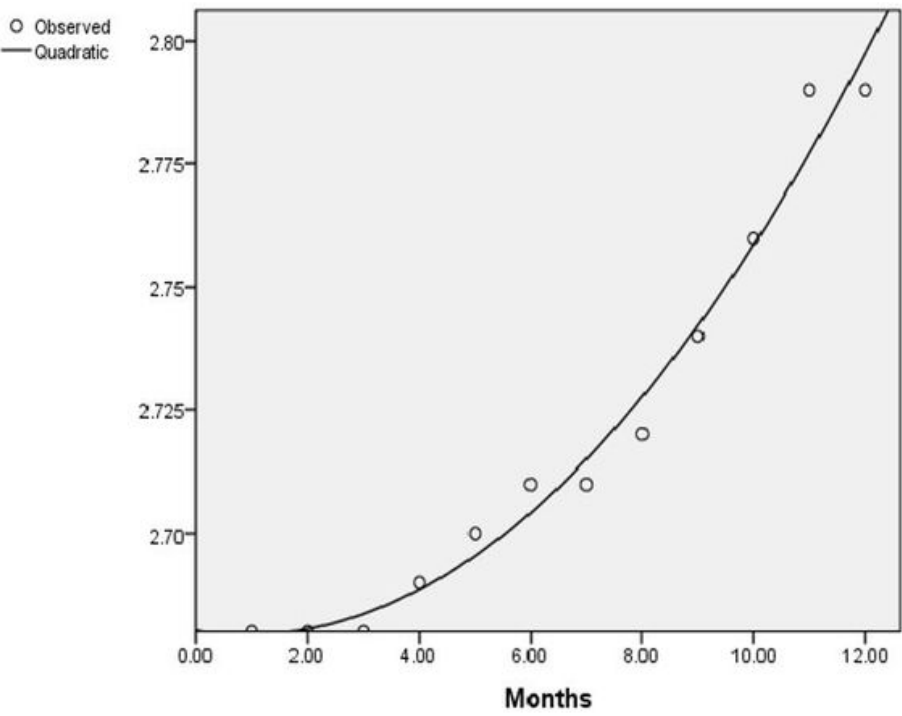

O Observed

- Quadratic

\section{Figure 2}

a Quadratic model for plant spread (N-S) during 2015-16 b Quadratic model for plant spread (N-S) during 2016-17

Spread

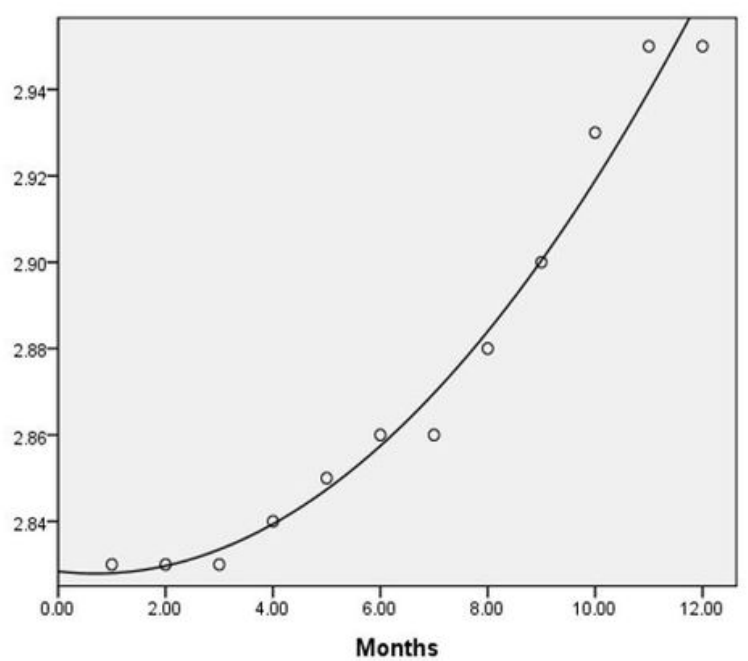

Spread

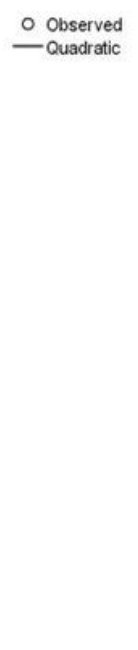

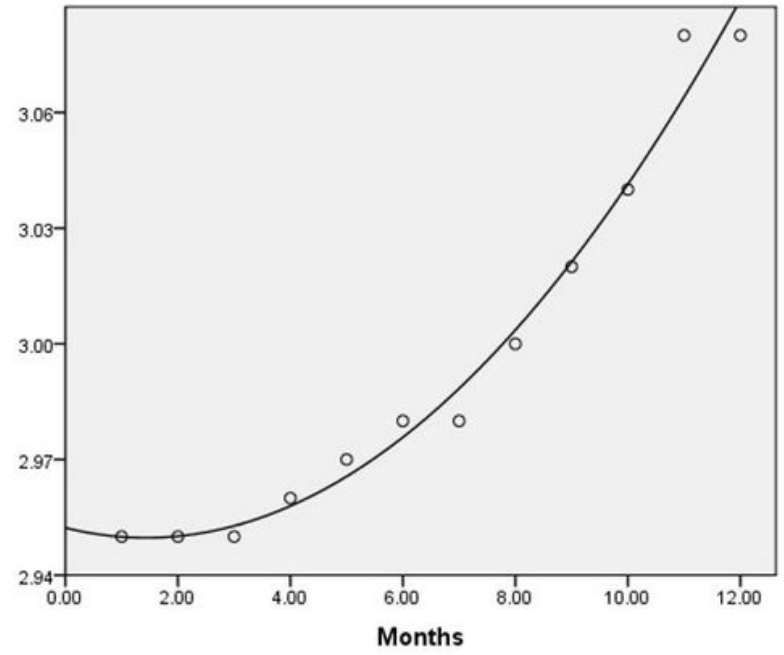

O Observed - Quadratic

\section{Figure 3}

a Quadratic model for spread (E-W) during 2015-16. b Quadratic model for spread (E-W) during 2016-17 

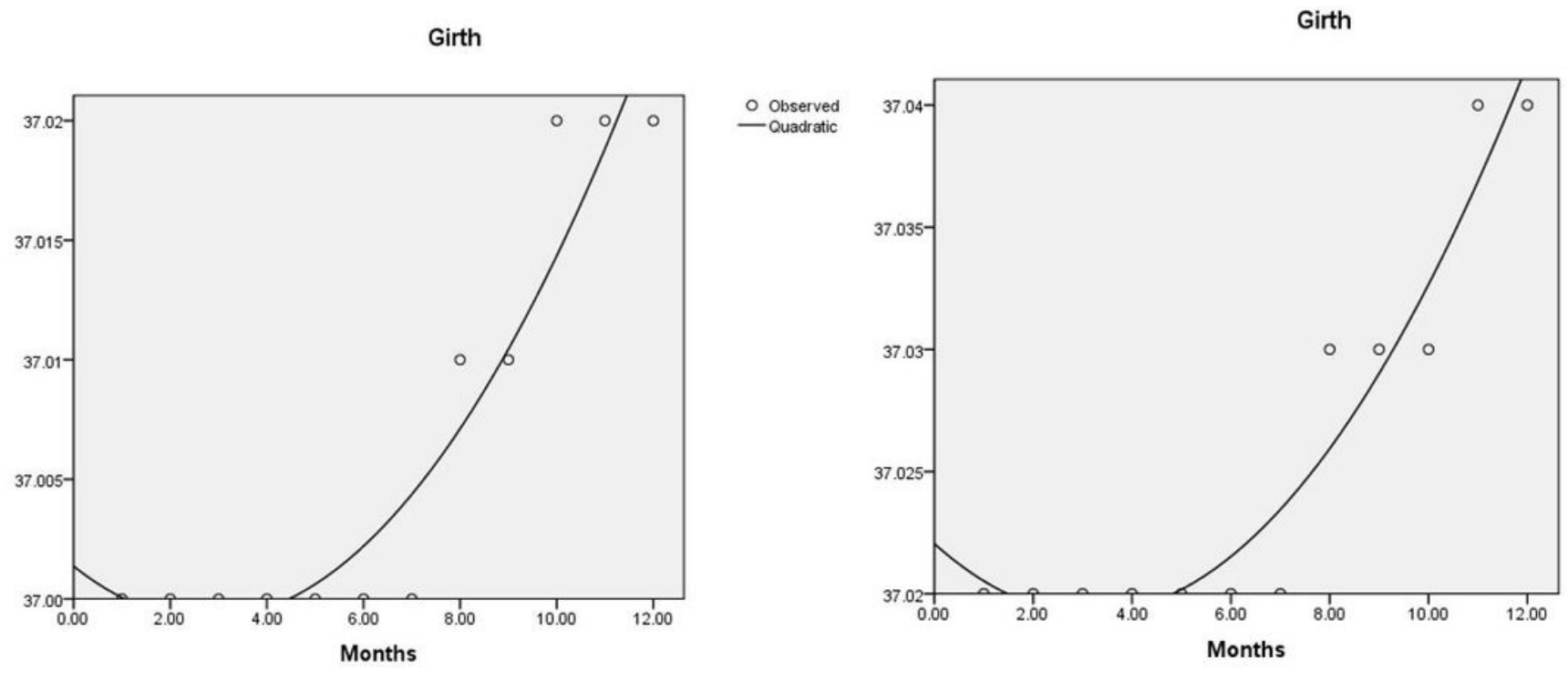

O Observed

Figure 4

a Quadratic model for trunk girth 2015-16. b Quadratic model for trunk girth during 2016-17
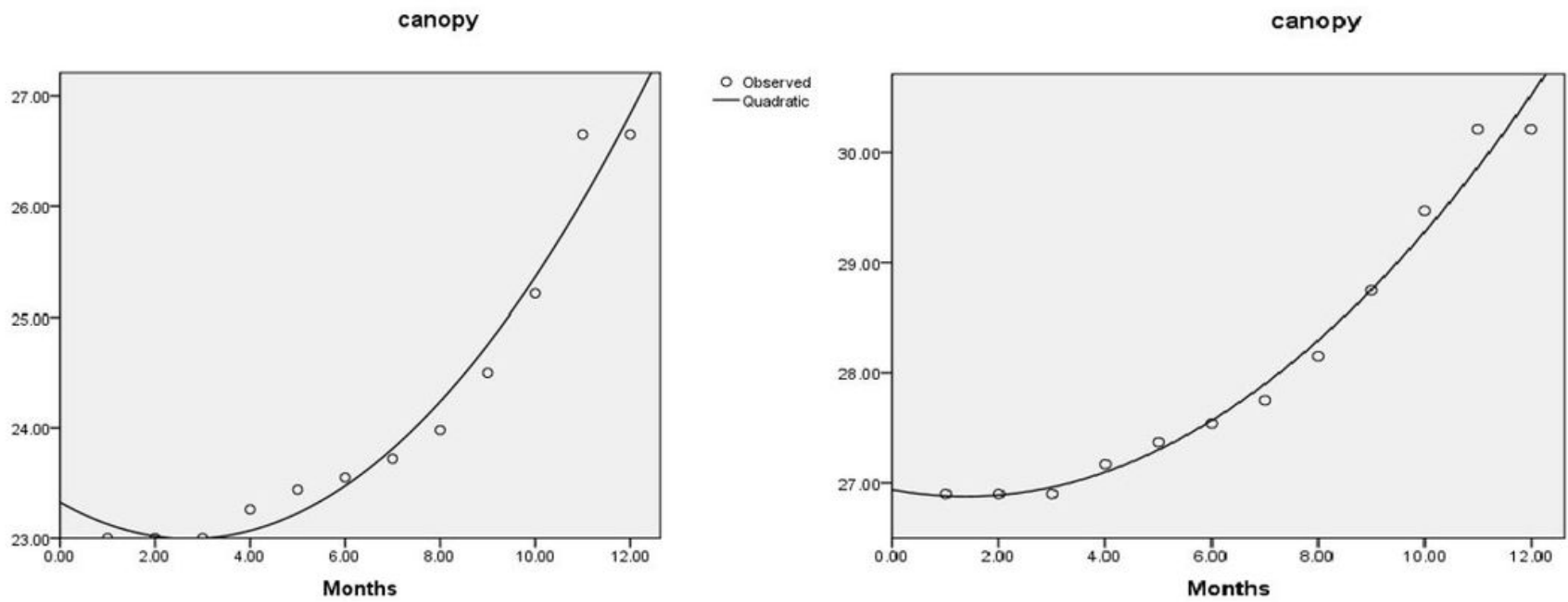

\section{Figure 5}

a Quadratic model for canopy volume during 2015-16. b Quadratic model for canopy volume during 2016-17 

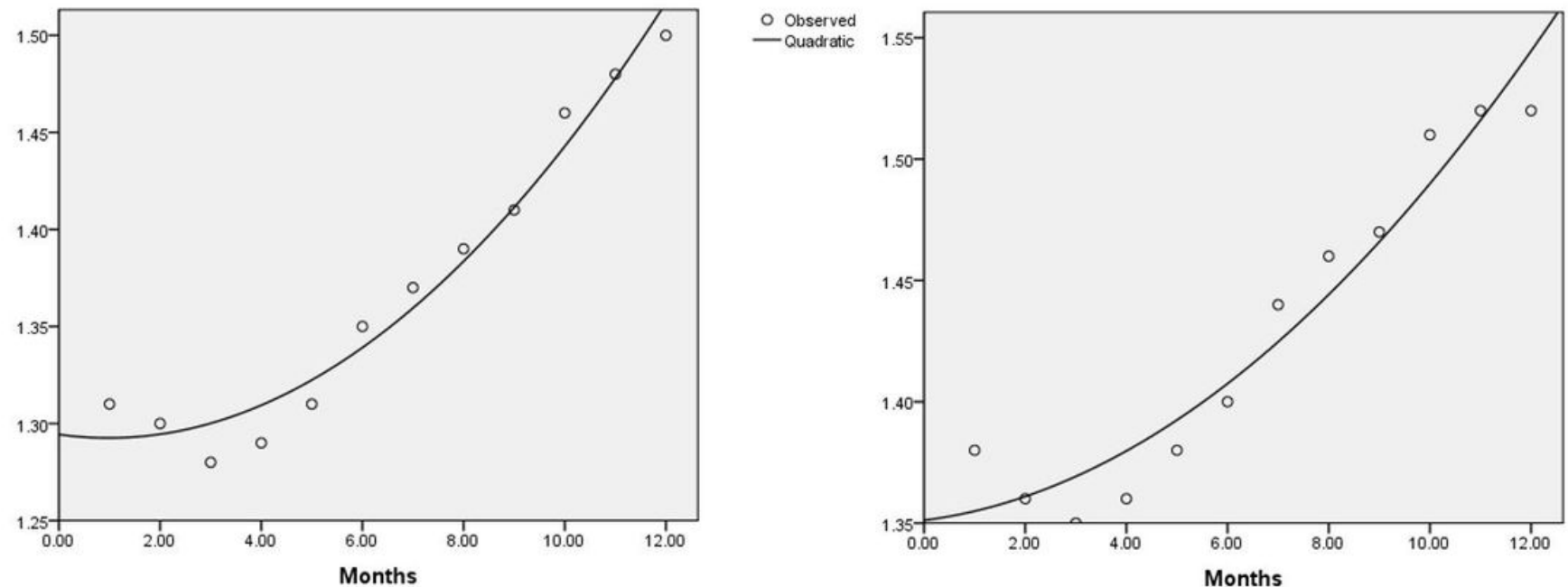

Figure 6

a Quadratic model for leaf chlorophyll during 2015-16. b Quadratic model for leaf chlorophyll during 2016-17

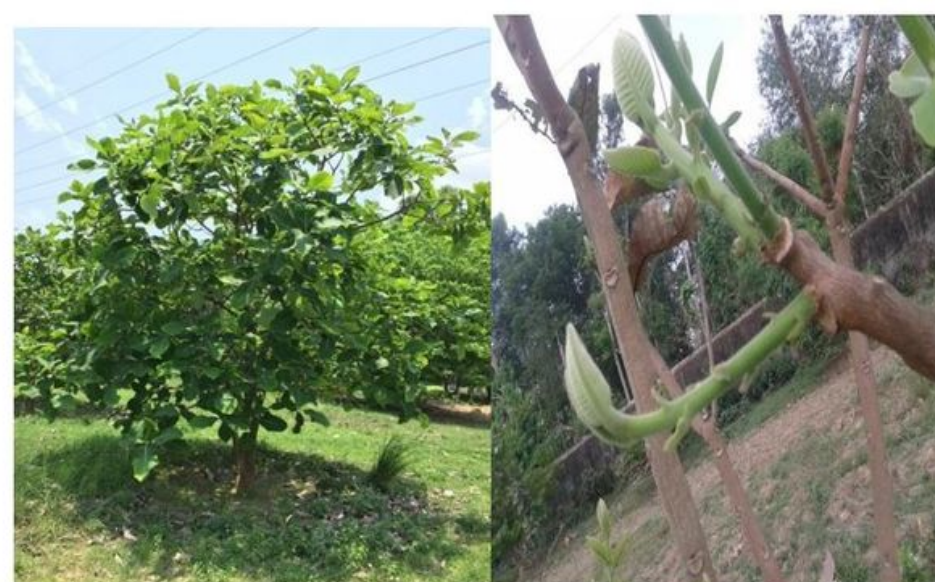

Growing plant

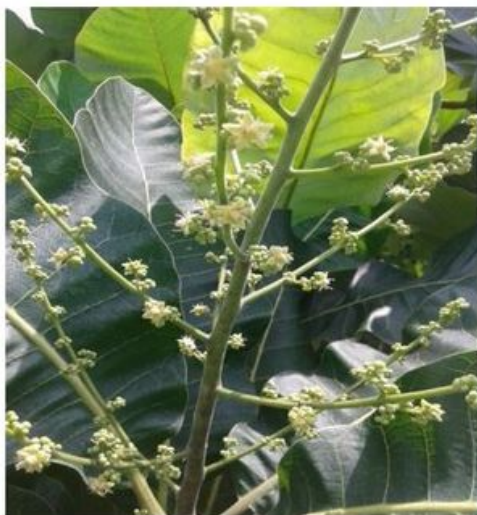

Anthesis
New leaf initiation

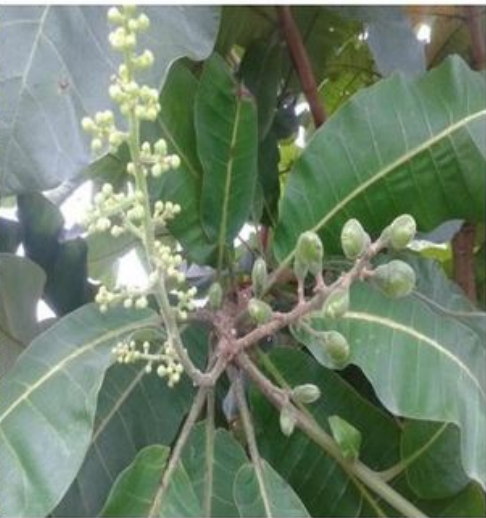

Fruit set

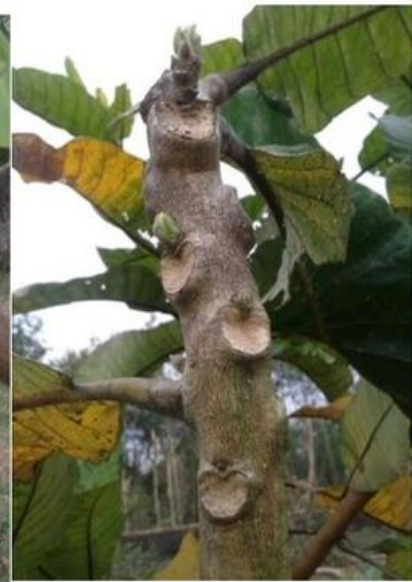

Leaf scar

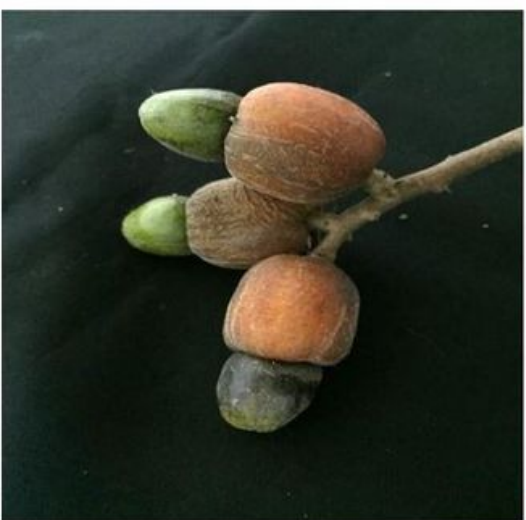

Fully mature fruit

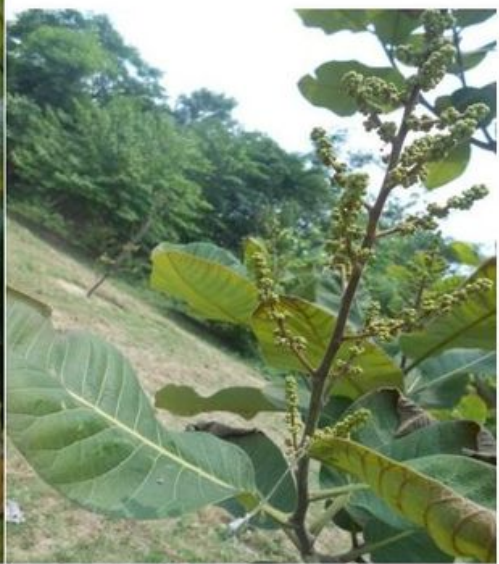

Flower bud

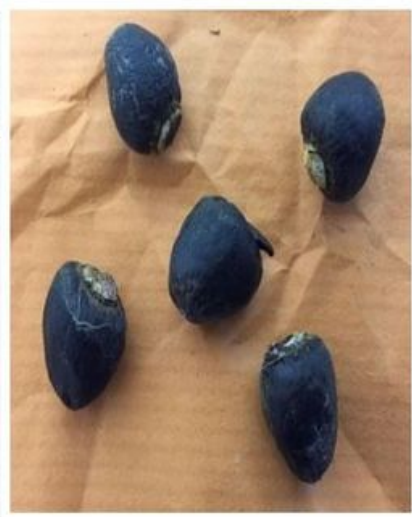

Bhela nut

Figure 7

General view of the bhela plant in the experimental plot 